\title{
Dimension and Crushed Stones Extraction as a Source of Social and Environmental Conflicts in Poland
}

\author{
Justyna Górniak-Zimroz * (D) and Katarzyna Pactwa \\ Faculty of Geoengineering, Mining and Geology, Wroclaw University of Science and Technology, \\ 50-370 Wrocław, Poland; katarzyna.pactwa@pwr.edu.pl \\ * Correspondence: justyna.gorniak-zimroz@pwr.edu.pl; Tel.: +48-71-320-6827
}

Received: 30 July 2018; Accepted: 11 October 2018; Published: 15 October 2018

\begin{abstract}
Crushed and dimension stones, which include 33 lithological varieties among igneous rocks, metamorphic rocks and sedimentary rocks, are mainly located in the southern and south-western part of Poland. Demand for this group of minerals is continuously high, which results from conducted and planned infrastructural investments. Mining activity is associated with interference in the natural environment. Negative consequences of exploitation include, among others: Land surface deformations, and the pollution of the soil, air, and water. In many cases, the extraction of minerals also leads to the liquidation of housing and transportation infrastructure located in the mining area, as well as to reducing the value of real estate in the immediate vicinity of the deposit or to increase in the level of stress among local residents, who are exposed to noise, which causes growing social conflicts in areas designated for exploitation. Thus, the awareness of negative effects of undertaking open-cast mining leads to the conflicts between various groups of stakeholders (residents, environmental organizations, mining entrepreneurs). Through the use of multi-criteria evaluation, this article identifies the places of potential social and environmental conflicts resulting from the planned mining activity in three areas of the densest occurrence of the analysed deposits (Lower Silesia Province, Lesser Poland Province and Świętokrzyskie Province). The assessment of lands over the deposits recognized initially and in detail was proposed, determining the degree of their accessibility. Due to the proposed method, it's possible to obtain results of the classification of each fragment of the analysed deposit, as well as the surroundings of such deposit at any distance from it, within the boundaries of analysed area. Information may be made available to users of the deposits, mining enterprises interested in exploitation of the deposits or administration responsible for issuing decisions regarding concessions for exploitations of the deposits, so that they have knowledge about conflict areas in the region, resulting from the impact of planned mining activity on life and health of the people and on the environment.
\end{abstract}

Keywords: rock raw materials; environmental protection; multi-criteria evaluation

\section{Introduction}

Mining is defined as a science covering issues associated with searching and recognition of deposit resources, works that prepare and make the deposits accessible, exploitation of deposits, transport and processing of minerals, as well as reclamation and development of post-mining area. Each stage of mining activity may constitute a source of environmental and social conflicts, due to interference in the natural environment and impact on health and life of the people. The nature and size of these conflicts depend on the type of raw material, on the size of extraction and on the technologies used to exploit and process the minerals. This article describes the methodology for assessing the accessibility of lands over the deposits of crushed and dimension stones recognized initially and in detail (unexploited), in order to identify potential environmental and social conflicts associated with the planned future 
mining activity. Issues associated with the difficulty in the scope of undertaking mining operations constitute a current topic in Polish, European, as well as global mining. Local communities living in the areas where future exploitation is foreseen usually believe in the NIMBY (not in my backyard) principle and they have unfavourable attitude towards the undertaking of any initiatives of mining entities that interfere with the surrounding infrastructure and environment [1-5].

\section{Materials and Methods}

Deposits of crushed and dimension stones are used to build road infrastructure (crushed aggregates, cobblestone, slabs, curbs), railway infrastructure (crushed aggregates) and in construction (crushed aggregates, blocks, slabs, wall stone). Deposits selected for the analyses included crushed stones and dimension stones covering 33 lithological varieties of igneous rocks (basalts, diabases, gabbros, granites, granodiorites, erratic boulders, syenites, andesites, porphyry, melaphyres, porphyric tuffs), sedimentary rocks (dolomites, marls, travertines, limestones, dolomitic limestones, conglomerates, limestones and dolomites, quartzites, grywacke, sandstones, quartzite sandstones, chalcedonites, gaizes, menilite shales, shales) and metamorphic rocks (amphibolites, serpentinites, greenschists, gneisses, shale hornfels, migmatites, crystalline shales, marbles, dolomitic marbles), which are characterized by specific properties deciding about their economic use. The above-mentioned group of raw materials does not occur evenly throughout Poland. The largest quantity of deposits of crushed and dimension stones can be found in: Lower Silesia Province (272 deposits with $42.2 \%$ share of national extraction of the crushed and dimension stones), Świętokrzyskie Province (137 deposits with 34.9\% share in the extraction) and Lesser Poland Province (105 deposits with the share in national extraction at the level of 12.1\%) [6], which is shown in Figure 1. Therefore, these three provinces were selected as area range in further analyses.

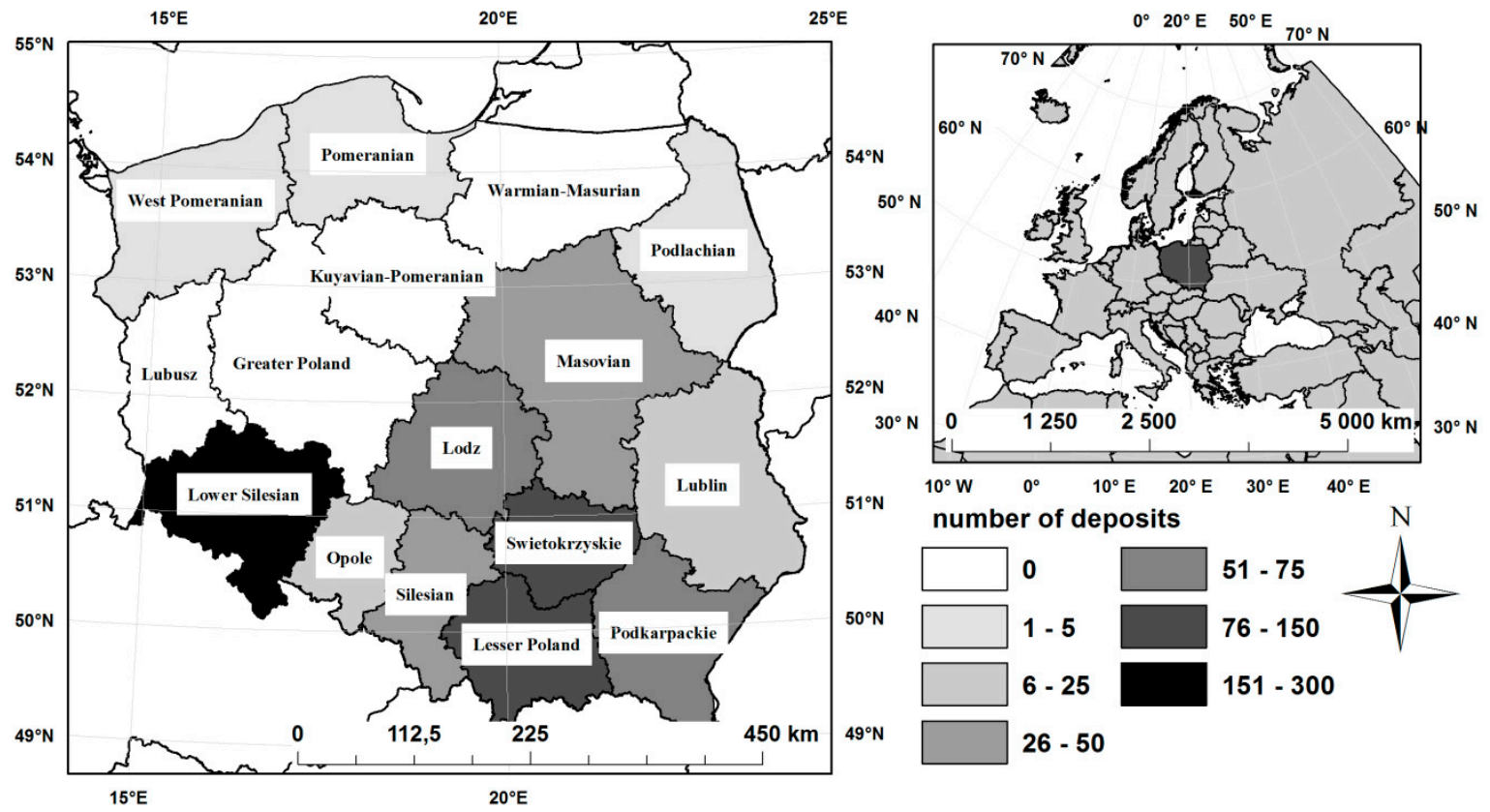

Figure 1. Dimension and crushed stone deposits in Poland.

On the basis of studies [7-14], Table 1 presents the impact of opencast mining activity on the environment and society, resulting from the exploitation of deposits of crushed and dimension stones, with division into the stages of conduct, which is the source of environmental and social conflicts. The listed methods of impact consider the division into the environment and society, which is continued in further analyses. 
Table 1. Mining activity stages and their impact on the environment and society.

\begin{tabular}{|c|c|c|}
\hline Mining Activity Stage & Impact on the Environment & Impact on the Society \\
\hline $\begin{array}{l}\text { Deposit exploration and } \\
\text { documentation }\end{array}$ & $\begin{array}{l}\text { Change in earth's surface } \\
\text { Traffic pollution emission } \\
\text { Dust pollution emission } \\
\text { Noise and vibration }\end{array}$ & $\begin{array}{l}\text { Traffic pollution emission } \\
\text { Dust pollution emission } \\
\text { Noise and vibration }\end{array}$ \\
\hline Preparation and enabling works & $\begin{array}{l}\text { Relief transformation } \\
\text { Geological formation change } \\
\text { Soil and land transformation } \\
\text { Destruction and pollution of living ecological features of plant and animal systems } \\
\text { Hydrological and hydrogeological transformation } \\
\text { Traffic pollution emission } \\
\text { Dust pollution emissionImpulse and steady noise, as well as vibration } \\
\text { Exclusion of land from the previous use }\end{array}$ & $\begin{array}{l}\text { Relief transformation } \\
\text { Change of land development method } \\
\text { Eradicating cultivation and breeding } \\
\text { Liquidation of residential, transportation and industrial infrastructures } \\
\text { Changes in real property values } \\
\text { Change of place of residence and lifestyle } \\
\text { Traffic pollution emission } \\
\text { Dust pollution emission } \\
\text { Impulse and steady noise, as well as vibration }\end{array}$ \\
\hline Mining & $\begin{array}{l}\text { Relief transformation } \\
\text { Geological formation change } \\
\text { Soil and land transformation } \\
\text { Destruction and pollution of living ecological features of plant and animal systems } \\
\text { Hydrological and hydrogeological transformation } \\
\text { Traffic pollution emission } \\
\text { Dust pollution emission } \\
\text { Impulse and steady noise, as well as vibration } \\
\text { Exclusion of land from the previous use }\end{array}$ & $\begin{array}{l}\text { Relief transformation } \\
\text { Change of land development method } \\
\text { Eradicating cultivation and breeding } \\
\text { Liquidation of residential, transportation and industrial infrastructures } \\
\text { Changes in real property values } \\
\text { Change of place of residence and lifestyle } \\
\text { Traffic pollution emission } \\
\text { Dust pollution emission } \\
\text { Impulse and steady noise, as well as vibration }\end{array}$ \\
\hline Processing & $\begin{array}{l}\text { Traffic pollution emission } \\
\text { Dust pollution emission } \\
\text { Impulse and steady noise, as well as vibration }\end{array}$ & $\begin{array}{l}\text { Traffic pollution emission } \\
\text { Dust pollution emission } \\
\text { Impulse and steady noise, as well as vibration }\end{array}$ \\
\hline Loading and transport & $\begin{array}{l}\text { Traffic pollution emission } \\
\text { Dust pollution emission } \\
\text { Impulse and steady noise, as well as vibration } \\
\text { Direct and indirect threats and nuisances related to raw material transportation }\end{array}$ & $\begin{array}{l}\text { Traffic pollution emission } \\
\text { Dust pollution emission } \\
\text { Impulse and steady noise, as well as vibration } \\
\text { Direct and indirect threats and nuisances related to raw material } \\
\text { transportation }\end{array}$ \\
\hline $\begin{array}{l}\text { Liquidation of the mining plant } \\
\text { Reclamation and development }\end{array}$ & $\begin{array}{l}\text { Relief transformation } \\
\text { Soil and land transformation } \\
\text { Flora and fauna transformation } \\
\text { Hydrological and hydrogeological transformation } \\
\text { Traffic pollution emission } \\
\text { Dust pollution emission } \\
\text { Impulse and steady noise, as well as vibration }\end{array}$ & $\begin{array}{l}\text { Change of land development method } \\
\text { Relief transformation } \\
\text { Traffic pollution emission } \\
\text { Dust pollution emission } \\
\text { Impulse and steady noise, as well as vibration }\end{array}$ \\
\hline
\end{tabular}


Information regarding the places of environmental and social conflicts associated with the planned mining activity is significant for the user of the deposit, when making a decision about the commencement of procedure related to obtaining a concession for the exploitation of mineral from the deposit. In the application for the concession, it's necessary to attach the evidence of existence of specific circumstances, described in the application, including circumstances associated with environmental protection (e.g., location on forest land, in the national parks with protection zones, in nature reserves, landscape parks with protection zones, in protected landscape areas, in Natura 2000 sites, ecological lands and nature-landscape complexes) and impact of exploitation on the society (e.g., location in the vicinity of housing development, hospitals, nursing homes, buildings associated with permanent or long-term stay of children and youth, spa and recreational areas), provided for by environmental protection regulations.

In order to assess the accessibility of lands over the deposits of crushed and dimension stones recognized initially and in detail, the methodology schematically presented in Figure 2 was used, which is based on Multi-Criteria Evaluation (MCE) that is aimed at choosing the optimal solution, determined according to various criteria that are difficult to compare with each other and affecting the implementation, as well as functioning of the given solution. These analyses are used as a tool supporting the decision-making process in the case when multiple criteria are available. An example of the application of MCE in research regarding the support of decision-making processes are the cases described, among others in the works [15-26]. The purpose of conducted assessment is to obtain information about conflict areas associated with the future conduct of mining activities and division of studied deposits into classes of accessibility. In accordance with [27], the accessibility was described in the research using the following equation:

$$
S=\sum_{i=1}^{n} w_{i} \times p_{i}
$$

where:

$S$-accessibility of the land

$w$-weight of the criterion (Table 2$), w_{i} \in[0,1]$

$p$-criterion value (Table 2), takes the value 1 when the criterion exists and 0 when it does not exist

$i$-criterion, $i \in\langle 1, n\rangle$

$n$-number of the criterion

For example: $\mathrm{S}_{\mathrm{SM}}=$ forms_of_higher_nature $\times 0.022+$ forms_of_lower nature $\times 0.017+$ prot_for $\times 0.015+$ prod_for $\times 0.024+$ other_for $\times 0.028+\ldots+$ mining_lands $\times 0.051$

$$
\sum_{i=1}^{n} w_{i}=1
$$

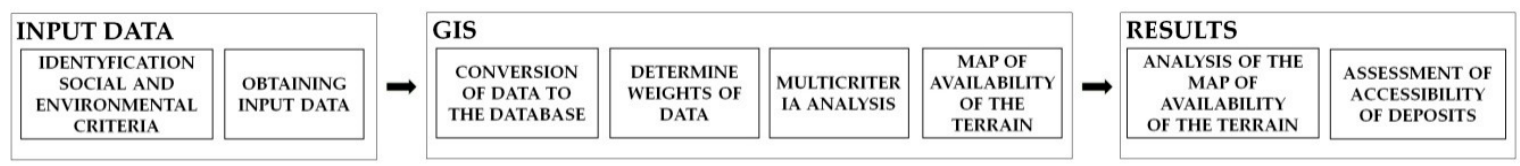

Figure 2. Methodology for assessing the accessibility of deposits of crushed and dimension stones in the environmental and social aspect.

Environmental and social criteria for the accessibility of land over the deposits of crushed and dimension stones were determined on the basis of works describing the impact of exploitation of crushed and dimension stone deposits (using the opencast method) on the environment and society [7-14], legal acts associated with the environmental protection [28-32], and own experiences of the authors of the article [20,33-35]. 19 criteria were identified (Table 2), which were subjected to 
surveying with participation of a group of respondents consisting of specialists engaged in mining, environmental protection and spatial management, in order to determine the weights for the social model and environmental model. The surveyed group was informed about purpose of the analysis, subject of the research and territorial limitation to the administrative boundaries of the Lower Silesia Province, Lesser Poland Province and Świętokrzyskie Province. After receiving the results from the survey, the arithmetic mean was calculated from the weights (Table 2). In comparison to the previously conducted research [20], the analyses were simplified by reducing the number of criteria for accessibility of land above the deposits. This was necessary among others, due to limitations in the accessibility of input files that cover three provinces with their range: Lower Silesia Province, Lesser Poland Province and Świętokrzyskie Province.

Table 2. The accessibility criteria for dimension and crushed stone deposits for the social and environmental models.

\begin{tabular}{|c|c|c|c|}
\hline \multirow{2}{*}{ Group of Criteria } & \multirow{2}{*}{ Criterion } & \multicolumn{2}{|c|}{ Weights } \\
\hline & & SM & EM \\
\hline \multirow[t]{2}{*}{$\begin{array}{l}\text { Forms of nature } \\
\text { conservation, including } \\
\text { Natura } 2000 \text { areas }\end{array}$} & $\begin{array}{l}\text { Forms of higher nature conservation (national } \\
\text { park, natural reserve, landscape park, national } \\
\text { and landscape park buffer zones, natural } \\
\text { monument) }\end{array}$ & 0.022 & 0.100 \\
\hline & $\begin{array}{l}\text { Forms of lower nature conservation (protected } \\
\text { landscape area, landscape-nature protected areas, } \\
\text { Natura 2000, ecological site, documentation site) }\end{array}$ & 0.017 & 0.064 \\
\hline \multirow{3}{*}{ Forests } & Protection forests & 0.015 & 0.052 \\
\hline & Production forests & 0.024 & 0.038 \\
\hline & Other forests & 0.028 & 0.032 \\
\hline Surface waters & Surface water & 0.027 & 0.046 \\
\hline $\begin{array}{l}\text { Main Groundwater } \\
\text { Reservoirs }\end{array}$ & Main Groundwater Reservoirs & 0.018 & 0.038 \\
\hline \multirow{5}{*}{ Transport infrastructure } & Motorways and expressways & 0.061 & 0.027 \\
\hline & Main roads & 0.048 & 0.025 \\
\hline & Collective and local roads & 0.042 & 0.027 \\
\hline & Other roads & 0.050 & 0.022 \\
\hline & Railway infrastructure & 0.053 & 0.041 \\
\hline \multirow{3}{*}{ Built-up areas } & Multi-family and single-family housing & 0.083 & 0.022 \\
\hline & Industrial and commercial-service buildings & 0.225 & 0.099 \\
\hline & Other buildings & 0.024 & 0.009 \\
\hline Arable land & Arable land & 0.113 & 0.151 \\
\hline Grasslands & $\begin{array}{l}\text { Meadows, mixed crops, grasslands and natural } \\
\text { pastures }\end{array}$ & 0.045 & 0.090 \\
\hline Permanent crops & Orchards and plantations & 0.054 & 0.082 \\
\hline Mining areas & Mining lands and areas & 0.051 & 0.035 \\
\hline
\end{tabular}

Data describing the land over the deposit and its surroundings is necessary in order to determine environmental and social conflicts resulting from mining activity. Data for the analyses were obtained in digital form as files in the shp format from state sources, i.e., from the Head Office of Geodesy and Cartography (Database of Topographic Objects), General Directorate for Environmental Protection (forms of nature protection), Polish Geological Institute (Main Underground Water Reservoirs, boundaries of mining areas, boundaries of deposits), State Forests (Data Bank about forests) and Main Inspectorate for Environmental Protection (Corine Land Cover 2012 database). After receiving the data, each layer was cut to the boundaries of analysed area (Lower Silesia Province, Lesser Poland 
Province and Świętokrzyskie Province) and the vector data was converted to the raster format. Size of the pixel was dependent on the size of the objects. In order to maintain the precision of reflecting the geometry, a pixel equal to $10 \mathrm{~m}$ was assumed for all layers. ArcGIS 10.4 software (Esri Support; Redlands, CA, USA) was used for the calculations.

\section{Results}

The obtained results allowed to identify the places of potential environmental and social conflicts, resulting from the planned mining activity associated with the exploitation of crushed and dimension stone deposits in the Lower Silesia Province, Lesser Poland Province and Świętokrzyskie Province (Figure 1). These areas include 172 undeveloped deposits of crushed and dimension stones recognized initially or in detail, with geological balance resources meeting the economical prerequisites for the exploitation in the size of 3,534,663 thousand Mg (Table 3).

Table 3. Quantity of deposits recognized in detail and initially, along with the resources in selected provinces, status as of 31 December 2017 [6].

\begin{tabular}{ccccccc}
\hline \multirow{2}{*}{ Deposit Types } & \multicolumn{2}{c}{ Lower Silesian } & \multicolumn{2}{c}{ Swietokrzyskie } & \multicolumn{2}{c}{ Lesser Poland } \\
\cline { 2 - 7 } & Quantity & $\begin{array}{c}\text { Resources } \\
\text { [thous. Mg] }\end{array}$ & Quantity & $\begin{array}{c}\text { Resources } \\
\text { [thous. Mg] }\end{array}$ & Quantity & $\begin{array}{c}\text { Resources } \\
\text { [thous. } \mathbf{M g} \text { ] }\end{array}$ \\
\hline $\begin{array}{c}\text { Deposits recognized in detail } \\
\text { Deposits recognized initially }\end{array}$ & 72 & 1003473 & 41 & 815754 & 26 & 212197 \\
Sum: & 12 & 661406 & 11 & 558350 & 10 & 283483 \\
& 84 & 1664879 & 52 & 1374104 & 36 & 495680 \\
\hline
\end{tabular}

Their exploitation may turn out to be impossible, due to environmental and social conflicts that may occur in the lands over the deposits or in their vicinity. Therefore, the assessment of accessibility of land over the deposits from an environmental (environmental model) and social (social model) perspective was conducted in the research, taking into account 19 limitations (Table 2). As a result of multi-criteria evaluation, the maps of accessibility and conflicts of areas in the Lower Silesia Province, Lesser Poland Province and Świętokrzyskie Province were obtained for the environmental model and social model (Figure 3). In the scope of resulting maps, a five-level division was used that classified the lands as: Non-conflict accessible lands, conflict and accessible lands with small limitations, conflict and accessible lands with medium limitations, conflict and accessible lands with great limitations, or conflict and inaccessible lands (Figure 3, Table 4).

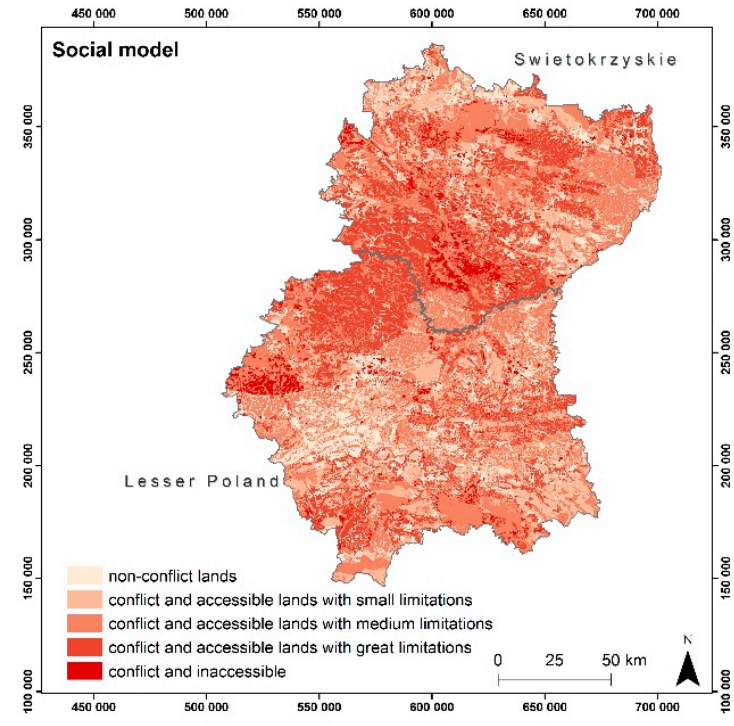

(a)

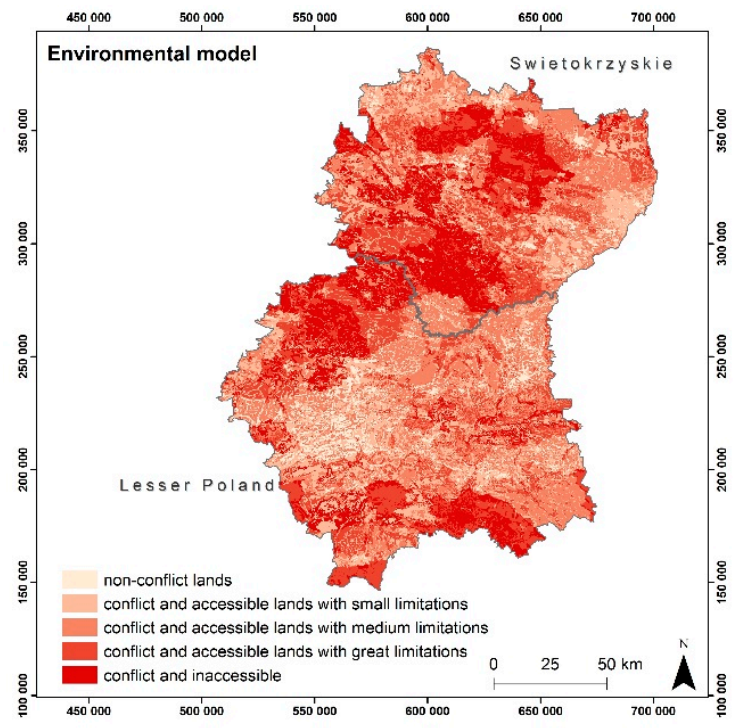

(b)

Figure 3. Cont. 


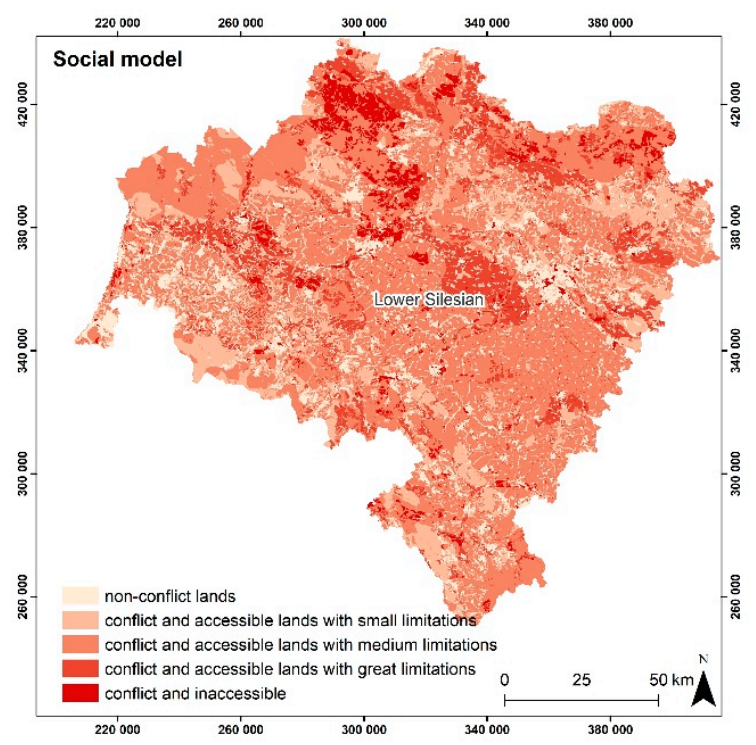

(c)

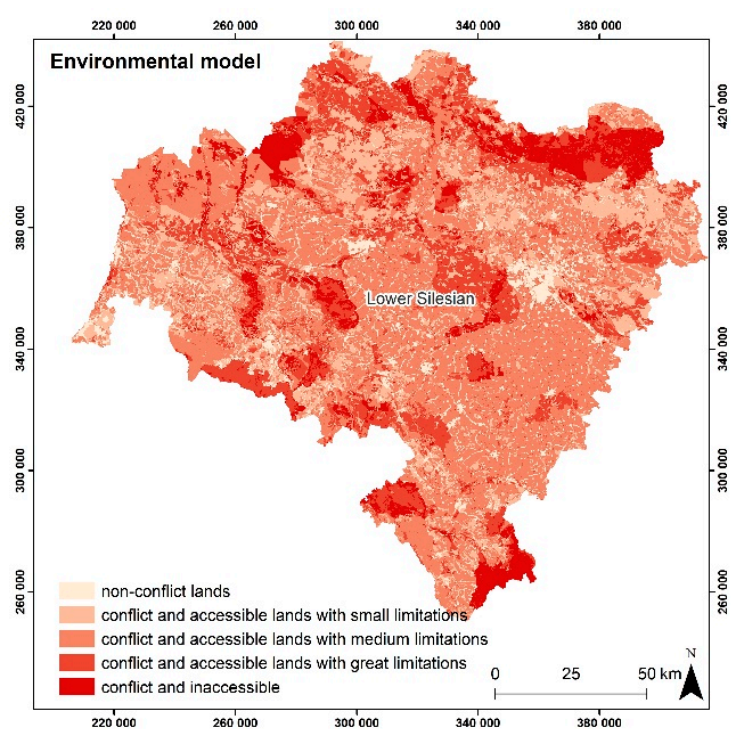

(d)

Figure 3. The result of the multi-criteria analysis for the environmental $(\mathbf{b}, \mathbf{d})$ and the social $(\mathbf{a}, \mathbf{c})$ model.

Table 4. Classes of accessibility of lands over the undeveloped dimension and crushed stone deposits (for selected province).

\begin{tabular}{ccccccccc}
\hline \multirow{2}{*}{$\begin{array}{c}\text { Classes of Accessibility of Lands } \\
\text { Over Deposits }\end{array}$} & \multicolumn{2}{c}{ Lower Silesian } & \multicolumn{2}{c}{ Swietokrzyskie } & Lesser Poland & \multicolumn{2}{c}{ Total Area } \\
\cline { 2 - 8 } & SM & EM & SM & EM & SM & EM & SM & EM \\
\hline $\begin{array}{c}\text { I non-conflict lands } \\
\text { II conflict and accessible lands with } \\
\text { small limitations }\end{array}$ & $26.0 \%$ & $2.7 \%$ & $0.1 \%$ & $0.0 \%$ & $0.2 \%$ & $0.1 \%$ & $9.3 \%$ & $1.0 \%$ \\
$\begin{array}{c}\text { III conflict and accessible lands with } \\
\text { medium limitations }\end{array}$ & $41.8 \%$ & $28.2 \%$ & $0.1 \%$ & $4.8 \%$ & $0.2 \%$ & $15.9 \%$ & $7.8 \%$ & $15.0 \%$ \\
$\begin{array}{c}\text { IV conflict and accessible lands with } \\
\text { great limitations }\end{array}$ & $5.6 \%$ & $21.5 \%$ & $11.5 \%$ & $15.5 \%$ & $1.9 \%$ & $23.5 \%$ & $7.8 \%$ & $18.9 \%$ \\
$\begin{array}{c}\text { V conflict and inaccessible lands } \\
\text { V }\end{array}$ & $4.7 \%$ & $5.4 \%$ & $59.3 \%$ & $78 \%$ & $52.6 \%$ & $50.4 \%$ & $38.8 \%$ & $47.7 \%$ \\
\hline
\end{tabular}

Where: SM-Social Model, EM-Environmental Model.

The assignment of a given fragment of the study to the class was determined by the value assigned to each pixel (gridcode), which was the result of multi-criteria evaluation calculations performed with the use of weighted sum method. A higher value means greater limitations of accessibility. The obtained results were multiplied by $\times 100$ and written down in a form of integers. In the case of environmental model, it was a value from 0 to 52, while for the social model it was a value from 0 to 58 .

On the other hand, the range of values corresponded to each of the classes in the models, depended on the percentage share of the class area in the entire analysed area, covering the three provinces. In the case of environmental model, non-conflict accessible lands cover the range $0-2$ and occupy $10.9 \%$ of the analysed area, conflict and accessible lands with small limitations cover the range 3-10 and $17.4 \%$, conflict and accessible lands with medium limitations cover the range 11-15 and 36.2\%, conflict and accessible lands with great limitations cover the range 16-21 and $22.8 \%$, conflict and inaccessible lands cover the range $22-52$ and $12.7 \%$. In the case of social model, non-conflict accessible lands assume value from the range $0-1$ in the gridcode field and occupy $13.7 \%$ of the analysed area, conflict and accessible lands with small limitations cover the range $2-4$ and $19.6 \%$, conflict and accessible lands with medium limitations cover the range 5-11 and $43.1 \%$, conflict and accessible lands with great limitations assume values of the gridcode equal to $12-15$ and $19.6 \%$, while conflict and inaccessible lands cover the range $16-58$ and $4.0 \%$ of area. Width of the classes was mainly dictated by the condition that the boundary classes, compared to the remaining classes, occupy the smallest area of the analysed 
terrain. The class with the largest area in the case of both models was the middle class of accessibility. Impediment in the selection of class ranges-so that each of them in both models occupies the same area, was the assumption of the total gridcode values (the values change stepwise). However, this was necessary due to the need to convert the data to a vector format. The detailed classification for the environmental and social model is shown in Figure 4.

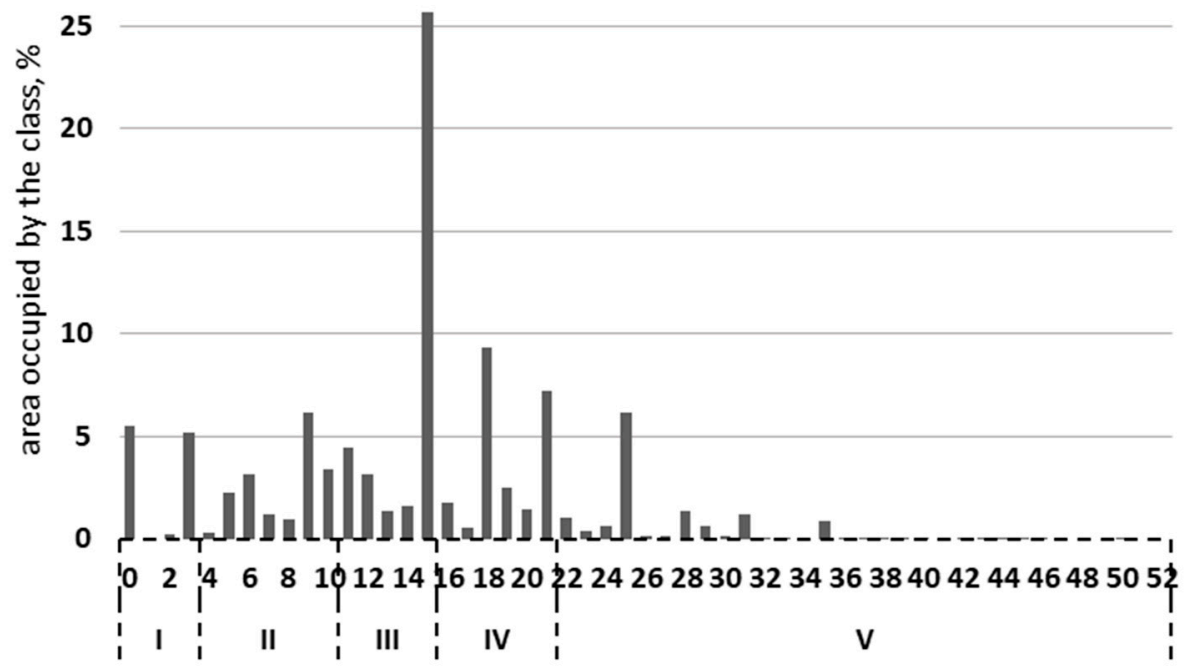

(a)

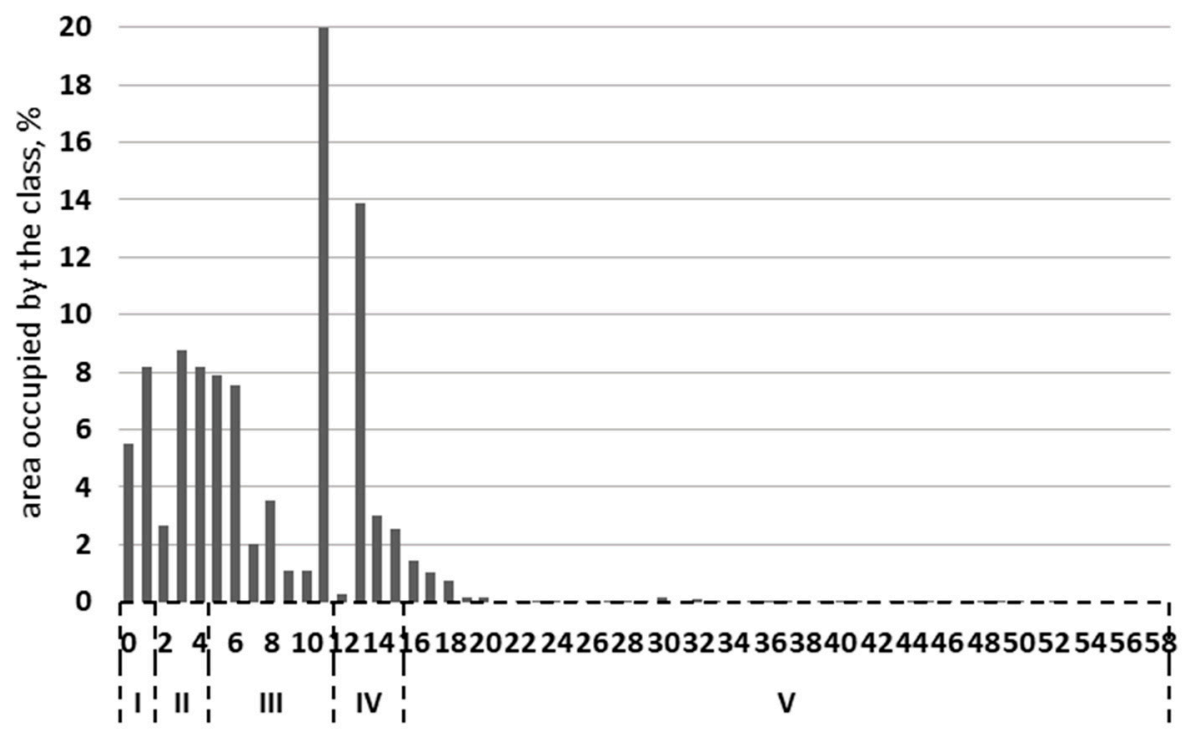

(b)

Figure 4. The category division in (a) the environmental, and (b) the social model, where on the $x$-axis Roman numbers I-V define classes of accessibility and Arabic numbers-gridcode.

In the subsequent stage, it was calculated and analysed what area of the deposits is assigned to each of the defined classes in the environmental model and social model. The results were used to assess the accessibility of analysed deposits from an environmental and social perspective. Percentage share of the area of deposits located in the lands is presented in a five-grade scale of accessibility in Table 4.

\section{Discussion}

In accordance with the presented methodology, information was obtained regarding the assessment of the accessibility of lands over the deposits of crushed and dimension stones, located 
in the analysed area (Lower Silesia Province, Lesser Poland Province and Świętokrzyskie Province). A division into five classes of land accessibility for mining activity was proposed in the environmental model and social model.

The obtained results show what percentage of the area of unexploited deposits of crushed and dimension stones consistently belongs to each of the classes. In the case of the Lower Silesia Province, the largest area is occupied by the class III, both in the social model and environmental model, $41.9 \%$ and $42.2 \%$ of the land area over the analysed deposits, respectively. In the case of Świętokrzyskie Province, it is the class V: $59.3 \%$ of the area in the social model and as much as $78 \%$ in the environmental model. In the case of Lesser Poland Province, it is also the class V (with the highest degree of conflict). The above-mentioned indicates that the greatest difficulties may be encountered by entrepreneurs undertaking exploitation in the southern part of Poland. Moreover, the percentage share of individual classes in the lands over the deposits is not consistent with their share in the entire region. What are the weaknesses and strengths of the proposed methodology? 1. The results depend on the surveyed group. In order for them to be reliable, it should be differentiated and the experts should represent different groups of interests. Therefore, the susceptibility to manipulation is high. 2. All results presented in the article constitute a source of work with the use of tools for spatial analyses. Research units in the country have them at their disposal. Unfortunately, it may be impossible to conduct research by local government units (marshal offices, district offices or municipal offices), due to shortages of equipment and appropriate software. 3. Limitations in the scope of conducting analyses may also result from availability of input data. However, there is a tendency of publishing data to a more and more extensive degree by the authorities that have them at their disposal. 4. General scheme of conduct is universal, regardless of the size of the area or the type of mineral. The quantity of criteria taken into account may be reduced or more precisely specified, depending on intended use of the results, as well as the needs (e.g., preliminary examination).

\section{Conclusions}

Due to the proposed method, it's possible to obtain results of the classification of each fragment of the analysed deposit, as well as the surroundings of such deposit at any distance from it, within the boundaries of analysed area. Information may be made available to users of the deposits, mining enterprises interested in exploitation of the deposits or administration responsible for issuing decisions regarding concessions for exploitations of the deposits, so that they have knowledge about conflict areas in the region, resulting from the impact of planned mining activity on life and health of the people and on the environment. Such knowledge is useful to present the local community with reliable information regarding the occurrence of environmental and social conflicts in the places of planned mining activity, associated with the exploitation of deposits of crushed and dimension stones, at the information meetings organized e.g., by mining entrepreneurs or by local government units. Demonstrating whether the planned exploitation is actually located in conflict areas may convince the local community to accept it, during the conducted social dialogues, and it may minimize the impact of the NIMBY principle.

Author Contributions: J.G.-Z. and K.P., Conceptualization, Methodology, Validation, Formal Analysis, Investigation, Resources, Data Curation, Writing-Original Draft Preparation, Writing-Review \& Editing, Visualization, Supervision, Project Administration; J.G.-Z, Funding Acquisition.

Funding: This article was financed with the research projects no. 0401/0123/2017: Research on natural and anthropogenic environmental changes using geographic information technology and no. 0401/0048/18: New measuring, analytical, simulation and experimental research methods in mining and geology, as well as in geodesy and cartography.

Conflicts of Interest: The funders had no role in the design of the study; in the collection, analyses, or interpretation of data; in the writing of the manuscript, and in the decision to publish the results. 


\section{References}

1. Badera, J.; Kocoń, P. Moral panic related to mineral development projects—Examples from Poland. Resour. Policy 2015, 45, 29-36. [CrossRef]

2. Bloodworth, A.J.; Scott, P.W.; McEvoy, F.M. Digging the backyard: Mining and quarrying in the UK and their impact on future land use. Land Use Policy 2009, 26S, 317-325. [CrossRef]

3. Conde, M. Resistance to Mining. A Review. Ecol. Econ. 2017, 132, 80-90. [CrossRef]

4. Ranängen, H.; Lindman, Å. Exploring corporate social responsibility practice versus stakeholder interests in Nordic mining. J. Clean. Prod. 2018, 197, 668-677. [CrossRef]

5. Van der Plank, S.; Walsh, B.; Behrens, P. The expected impacts of mining: Stakeholder perceptions of a proposed mineral sands mine in rural Australia. Resour. Policy 2016, 48, 129-136. [CrossRef]

6. Brzezinski, D.; Miskiewicz, W. Dimension and crushed stone. In Balance of Mineral Deposits in Poland as of 31 XII 2017 the Year; Szuflicki, M., Malon, A., Tyminski, M., Eds.; Polish Geological Institute-National Research Institute: Warsaw, Poland, 2018; pp. 99-121. ISBN 978-83-7863-979-4.

7. Azapagic, A. Developing a framework for sustainable development indicators for the mining and minerals industry. J. Clean. Prod. 2004, 12, 639-662. [CrossRef]

8. Environmental Impacts of Mining Activities, Emphasis on Mitigation and Remedial Measures; Azcue, J.M. (Ed.) Springer: Berlin, Germany, 1999; pp. 1-311. ISBN 978-3-642-64169-5. [CrossRef]

9. Badera, J. Social conflicts on the environmental background related to development of mineral deposits in Poland. Min. Resour. Manag. 2010, 26, 105-125. (In Polish)

10. Badera, J. Problems of social non-acceptance of mining projects with particular emphasis on the European Union a literature review. Environ. Soc.-Econ. Stud. 2014, 2, 27-34. [CrossRef]

11. Lapcik, V.; Lapcikova, M. Environmental Impact Assessment of Surface Mining. Inzynieria Mineral. 2011, 1, 1-10.

12. Hu, Z. Legislation, Technology and Practice of Mine Land Reclamation; The Beijing International Symposium Land Reclamation and Ecological Restoration; A Balkema Book; Taylor \& Francis Group: Abingdon, UK, 2014; pp. 1-668.

13. Nieć, M.; Radwanek-Bak, B. Protection and Rational Use of Mineral Deposits; Publisher of the Institute of Economy of Mineral Resources and Energy of the Polish Academy of Sciences: Cracow, Poland, 2014; pp. 1-178. ISBN 978-83-62922-34-5. (In Polish)

14. Pietrzyk-Sokulska, E.; Uberman, R.; Kulczycka, J. The impact of mining on the environment in Poland-Myths and reality. Miner. Resour. Manag. 2015, 31, 45-64. [CrossRef]

15. Blachowski, J. Spatial analysis of the mining and transport of rock minerals (aggregates) in the context of regional development. Environ. Earth Sci. 2014, 71, 1327-1338. [CrossRef]

16. Blachowski, J.; Rybakiewicz, W.; Warczewski, W.; Malczewski, P. Application of multi-criteria analysis in GIS for optimal planning of house development areas. Case study of Wroclaw Functional Area. Ann. Geomat. 2016, 5, 561-571.

17. Chen, J. GIS-based multi-criteria analysis for land use suitability assessment in City of Regina. Environ. Syst. Res. 2014, 3-13. [CrossRef]

18. Eastman, J.R.; Van Fossen, M.E.; Solorzano, L.A. Transition potential modelling for Land-Cover change. In GIS, Spatial Analysis and Modelling; Maguire, D.J., Batty, M., Goodchild, F., Eds.; ESRI Press: Redlands, CA, USA, 2015; pp. 357-385. ISBN 10 978-1589481305.

19. Gonçalves Gomes, E.; Estellita Lins, M.P. Integrating Geographical Information Systems and Multi-Criteria Methods: A Case Study. Ann. Oper. Res. 2002, 116, 243-269. [CrossRef]

20. Górniak-Zimroz, J.; Pactwa, K. Method for assessment of the accessibility of dimension and crushed stone undeveloped deposits in Poland from the environmental and social perspective. Int. J. Min. Reclam. Environ. 2017. [CrossRef]

21. Kiker, G.A.; Bridges, T.S.; Varghese, A.; Seager, T.P.; Linkovjj, I. Application of Multicriteria Decision Analysis in Environmental Decision Making. Integr. Environ. Assess. Manag. 2005, 1, 95-108. [CrossRef] [PubMed]

22. Malczewski, J. GIS and Multicriteria Decision Analysis; John Wiley \& Sons: Hoboken, NJ, USA, 1999; pp. 1-392. ISBN 0-471-32944-4.

23. Malczewski, J. GIS based multicriteria decision analysis: A survey of the literature. Int. J. Geogr. Inf. Sci. 2006, 20, 703-726. [CrossRef] 
24. Omitaomu, O.A.; Blevins, B.R.; Jochem, W.C.; Mays, G.T.; Belles, R.; Hadley, S.W.; Harrison, T.J.; Bhaduri, B.L.; Neish, B.S.; Rose, A.N. Adapting a GIS-based multicriteria decision analysis approach for evaluating new power generating sites. Appl. Energy 2012, 96, 292-301. [CrossRef]

25. Qingjie, Z.; Hejmanowska, B. Analysis of GIS-based spatial variability and risk assessment. J. Chem. Pharm. Res. 2013, 5, 372-380.

26. Soltanmohammadi, H.; Osanloo, M.; Rezaei, B.; Aghajani Bazzazi, A. Achieving to some outranking relationships between post mining land uses through mined land suitability analysis. Int. J. Environ. Sci. Technol. 2008, 5, 535-546. [CrossRef]

27. Eastman, J.R. INDRISI 32 Release 2. Guide to GIS and Inage Processing; Clark Labs Clark University: Worcester, MA, USA, 2001; Volume 2, pp. 1-161.

28. Dz.U.2001.62.627 the Act of 27 April 2001 on Environment Protection. Available online: http:/ / prawo.sejm. gov.pl/isap.nsf/DocDetails.xsp?id=WDU20010620627 (accessed on 13 October 2018). (In Polish)

29. Dz.U.2002.165.1359 Regulation of the Minister of the Environment of 9 September 2002 on Soil Quality Standards and Earth Quality Standards. Available online: http:/ / prawo.sejm.gov.pl/isap.nsf/DocDetails. xsp?id=WDU20010620627 (accessed on 13 October 2018). (In Polish)

30. Dz.U.2004.92.880 the Act of 16 April 2004 of the Nature Conservation. Available online: http:/ / prawo.sejm. gov.pl/isap.nsf/DocDetails.xsp?id=WDU20040920880 (accessed on 13 October 2018). (In Polish)

31. Dz.U.2007.120.826 Regulation of the Minister of the Environment of June 142007 Regarding Permissible Noise Levels in the Environment. Available online: http:/ / prawo.sejm.gov.pl/isap.nsf/DocDetails.xsp?id= WDU20071200826 (accessed on 13 October 2018). (In Polish)

32. Dz.U.2011.163.981 the Act of 9 June 2011 on the Geological and Mining Law. Available online: http:/ / prawo. sejm.gov.pl/isap.nsf/DocDetails.xsp?id=WDU20111630981 (accessed on 13 October 2018). (In Polish)

33. Gorniak-Zimroz, J.; Pactwa, K. The use of spatial data in granite deposit life cycle assessment. Procedia Earth Planet. Sci. 2015, 15, 474-481. [CrossRef]

34. Gorniak-Zimroz, J.; Pactwa, K. Identification of social and environmental conflicts resulting from open-cast mining. Earth Environ. Sci. 2016, 44. [CrossRef]

35. Kazmierczak, U.; Gorniak-Zimroz, J. Institutional environmental protection and exploitation of rock deposits with open cast method. Min. Sci. 2015, 22, 85-100. [CrossRef] 